\title{
Analysis of Development Strategy Management of the Indonesian Navy Hospital dr. R. Oetojo
}

\author{
Satrio Sugiharto Machfudi*, Wahyu Wijaya**, Heri Iswanto *** \\ *M Author Correspondence: satrio_sugiharto@tnial.mil.id \\ *Command and Staff College, Indonesian Navy, Jakarta, Indonesia \\ **Command and Staff College, Indonesian Navy, Jakarta, Indonesia \\ ***Command and Staff College, Indonesian Navy, Jakarta, Indonesia
}

I N D E X I N G

Keywords:

Strategy management;

Health services;

Service quality;

Satisfaction;

SWOT;

\section{Kata kunci:}

Manajemen strategi;

Pelayanan kesehatan;

Kualitas pelayanan;

Kepuasan;

SWOT;

\begin{abstract}
A B S T R AC T
This study aims to analyze the strategic management of the Sorong Naval Hospital dr. R. Oetojo, Indonesian Navy development in an effort to provide personnel health services in the Sorong XIV Main Naval Base working area. The scope of the study includes the analysis of external environmental factors that become opportunities and threats, and analysis of internal environmental factors that become strengths and weaknesses, redefining the vision and mission, setting long-term goals until 2023, determining alternative strategies and determining the chosen strategy appropriate. The research method is operational with a combination of research data from interviews and questionnaires. Implementation performance and quality of health services consisting of dimensions of tangible, reliability, responsiveness, assurance, and empathy with an average index of 4.00 or $80.15 \%$ have good results. The strategy was chosen by using the SWOT matrix and IE matrix to obtain the organization's position. Health services Naval Hospital dr. R. Oetojo, Indonesian Navy based on the SWOT matrix analysis is in quadrant I, which is an aggressive strategy which replace with that, has a very profitable position or strategy, maximizes opportunities and strengths, and supports aggressive growth policies. The results of the IE matrix obtained the total value of the EFAS matrix 3.159 and IFAS matrix 3.203, so that the hospital position is in the cell I or is described as Grow and Build with alternative strategies including market penetration, market development, and product development.
\end{abstract}

Penelitian ini bertujuan untuk menganalisis manajemen strategi pengembangan RSAL dr. R Oetojo dalam upaya menyelenggarakan pelayanan kesehatan personel di wilayah kerja The Sorong XIV Main Naval Base. Ruang lingkup penelitian meliputi analisis faktor-faktor lingkungan eksternal yang menjadi peluang dan ancaman, dan analisis faktor-faktor lingkungan internal yang menjadi kekuatan dan kelemahan, menentukan kembali visi dan misi, menetapkan tujuan jangka panjang sampai dengan 2023, menentukan strategi alternatif serta menetapkan strategi terpilih yang sesuai. Metode penelitian operasional dengan kombinasi data penelitian hasil wawancara dan kuesioner. Kinerja pelaksanaan dan kualitas pelayanan kesehatan terdiri dari dimensi bukti fisik, kehandalan, daya tanggap, jaminan, dan perhatian dengan indeks rata-rata sebesar 4.00 atau $80.15 \%$ memiliki hasil yang baik. Strategi terpilih dengan menggunakan matriks SWOT dan matriks IE untuk mendapatkan posisi organisasi. Pelayanan kesehatan Naval Hospital dr. R. Oetojo, Indonesian Navy berdasarkan analisis matriks SWOT berada pada kuadran I yaitu strategi agresif dimana memiliki posisi atau letak strategi yang sangat menguntungkan, memanfaatkan peluang dan kekuatan secara maksimal, dan mendukung kebijakan pertumbuhan yang agresif. Hasil dari matriks IE diperoleh total nilai matriks EFAS 3.159 dan nilai matriks IFAS 3.203, sehingga didapatkan posisi rumah sakit berada pada sel I atau digambarkan sebagai Grow dan Build dengan strategi alternatif meliputi market penetration, marke development, dan product development.

(C) 2019 JMMR. All rights reserved

Article History: Received 2019-Aug-21; Revised 2019-Aug-23; Accepted 2019-Nov-20

\section{Introduction}

Health development is an integral part of national development. The Act no. 23 of 1992 concerning Health had stipulated that health is a state of complete physical mental, soul and social well being that enables everyone to live socially and economically productive. Health development goals are to increase awareness, willingness and ability of living healthy for everyone to achieve an optimal degree of public health. ${ }^{1}$ 
An improved degree of health was done through improving the quality and feasibility of equitable and affordable health care to the entire community, both geographically and economically that requires the provision of health care facilities. Hospital is one of compound health care facilities that have wide range of functions regarding function of enhancement, preventive, curative and rehabilitation bringing health services closer to community. ${ }^{2}$

Developments and changes of Indonesian Armed Forces health policies, directly or indirectly, will affect the pattern of support and health services within the Indonesian Armed Forces itself (abbreviated as TNI). Support and health services carried out by TNI health care should meet the needs of the military personnel and their families. Accordingly, the health aspects in supporting the main tasks of the Indonesian Armed Forces itself (abbreviated as TNI) will produce optimal results. ${ }^{3}$

It is an obligation for the hospital to create a health service management system which covers all the necessary aspects needed for the realization of an efficient service system and in accordance with the needs of community. Accordingly, a good management should be applied in order to demonstrate a satisfying health care provision for community. ${ }^{4}$

Management pattern, in its early development, that was applied to hospital authorities is always patterned on the internal interests of institution. However, it is shifted into a pattern that refers to the interests and demands of consumers. As a result, it is not surprising that many hospitals nowadays have developed their health care system into a consumers-based health care. ${ }^{5}$

Strategy management is a way of thinking and managing an organization that is not limited to how managing some activities can be performed in the organization, but also how to develop a new attitude with regard to external changes. An understanding of the significance of strategy management is not only limited to the aspects of implementation of the plan, but even further to the aspect of the vision, mission, and organizational purpose. $^{6}$

In general, a health care is any organized attempt alone or together in an organization to maintain and promote health, prevent and cure disease and revive health of individuals, families, groups and/or communities. The form and type of health care is determined by the service management, scope of activities and target of health services. $^{7}$

Health services stipulated in Presidential Regulation of the Republic of Indonesia Number 107 of 2013. Article 4 of the Military Medical Services include: a) members of the military health services related to operational activities; and b) Health services to support main duties and functions of the military. Further, related to the health services of military personnel regarding operational activities, stipulated in Article 5 of health services of military personnel (related to the operations) that referred to Article 4 letter a which includes: a) Providing medical support of military exercises; b) The provision of health support of military operations; c) medical examination of TNI personnel; d) health services as a result of training activities and military operations; and e) the promotive, preventive and rehabilitative health services. ${ }^{8}$

Taking into consideration the fact that recent condition with many limited of infrastructure, potential human resources, the primary health needs of Indonesian Armed Forces itself (abbreviated as TNI) personnel, Civil Servant (ASN), the other site is high demand families, and society are based on the utilization of the supporting medical services. Accordingly, it becomes the background of the researchers to conduct a research in Naval Hospital dr. R. Oetojo, Indonesian Navy as a reference of health care center of military personnel and their family in the working area of the Sorong XIV Main Naval Base.

\section{RESEARCH METHOD}

The study was conducted using the operational research method that consist of review and analysis of primary and secondary data, as well as the direct observation made to the situation and condition of management and service at the Naval Hospital dr. R. Oetojo, Indonesian Navy. The research data used in this study is mixed methods (Concurrent Triangulation Type), in which a combination of quantitative and qualitative research data conducted simultaneously to obtain a comprehensive analysis of the research problem. The qualitative research was done through depth interviews with several informants, data collection record and document, and data analysis. Quantitative research was done by collecting sample data from the questionnaire of personnel the Sorong XIV Main Naval Base and collecting secondary data such as documents, records, and reports. Processing primary data is through editing, coding, and tabulating. Further, the researchers performed the instrument testing in the form of validity test and reliability test. The secondary data is processed through coding, data input and analysis. The next stage was data testing in the form of normality test, homogeneity test, linearity test, and multiple linear regression analysis and the difference test with $\mathrm{t}$ test (partial) and $f$ test (simultaneous). The final stage was the interpretation of qualitative and quantitative data, and making conclusions and recommendations. 


\section{RESULT AND DISCUSSION}

The main function of Naval Hospital dr. R. Oetojo, Indonesian Navy is to provide medical support and health care services for outpatient and inpatient as well as a reference to the Medical Center of Health Office the Sorong XIV Main Naval Base, Indonesian Warship (abbreviated as KRI) health units operating in Sorong and primary health care service.

Table 1 and Table 2 below mentioned some of the human resources from the military and civil servants according to military rank and profession status or skill performing according with partners (collaboration labor), organic (fixed labor), free honorer labor (abbreviated as PHL) health service support in Naval Hospital dr. R. Oetojo, Indonesian Navy of Sorong City.

Table 1. Human Resources of the Sorong Naval Hospital dr. R. Oetojo, Indonesian Navy based on status ranks

\begin{tabular}{lcc}
\hline \multicolumn{1}{c}{ Human Resources } & Quantity & Description \\
\hline Officer (Perwira) & 7 & 40 \\
Non-Commissioned & & \\
Officer (Bintara) & 5 & 38 \\
Enlisted (Tamtama) & 2 & 7 \\
Civil Servant (PNS) & 5 & 48 \\
\multicolumn{1}{c}{ Total } & $\mathbf{1 9 ( 1 4 . 2 8 \% )}$ & $\mathbf{1 3 3}$ \\
\hline
\end{tabular}

Current conditions of the Sorong Naval Hospital dr. R. Oetojo, Indonesian Navy in terms of BOR report results (Bed Occupancy Ratio) between 2016 and 2017, respectively $58.7 \%$ and $61.5 \%$, that showed a significant increase, even though the hospital condition has not developed yet.

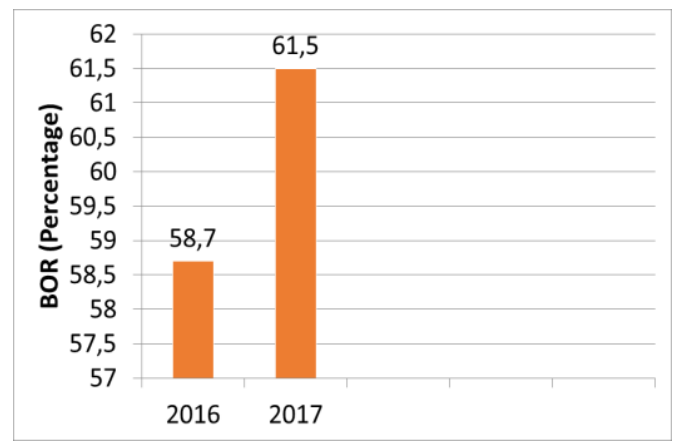

Figure 1. BOR of the Sorong Naval Hospital dr. R. Oetojo, Indonesian Navy

Source: Data of Naval Hospital dr. R. Oetojo, Indonesian Navy, 2018

ALOS (Average Long of Stay) between 2016 and 2017, respectively 3.7 and 3.5 , showed a decrease related to duration of treatment in the Sorong Naval Hospital dr. R. Oetojo, Indonesian Navy.

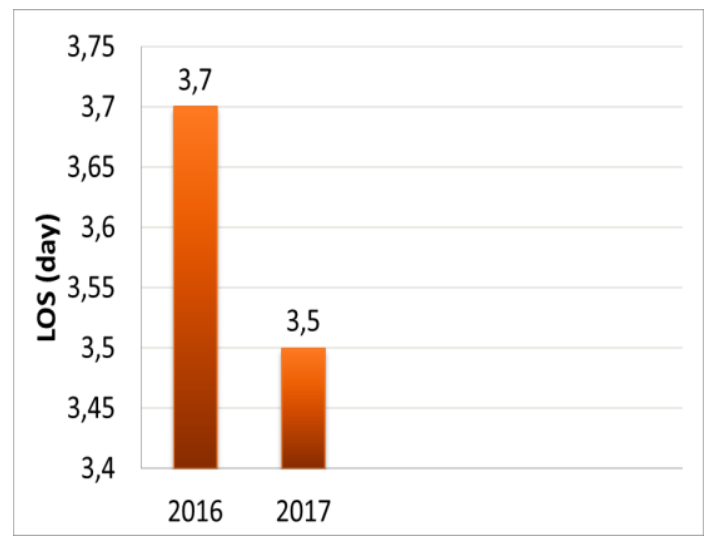

Figure 2. LOS of the Sorong Naval Hospital dr. R. Oetojo, Indonesian Navy

Source: Data of Naval Hospital dr. R. Oetojo, Indonesian Navy, 2018

BTO (Bed Turn Over) between 2016 and 2017, respectively 45 times and 30.2 times, showed a decrease in patient turnover in the Sorong Naval Hospital dr. R. Oetojo, Indonesian Navy.

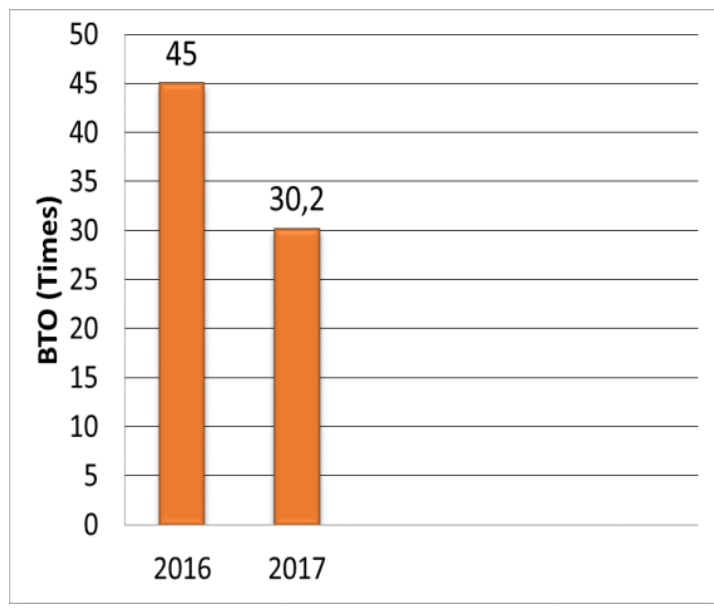

Figure 3. BTO of the Sorong Naval Hospital dr. R. Oetojo, Indonesian Navy

Source: Data of Naval Hospital dr. R. Oetojo, Indonesian Navy, 2018

TOI (Turn over Interval) between 2016 and 2017, respectively 3.3 days and 4.5 days, showed an increase in turnover interval of patient visits in the Sorong Naval Hospital dr. R. Oetojo, Indonesian Navy. 


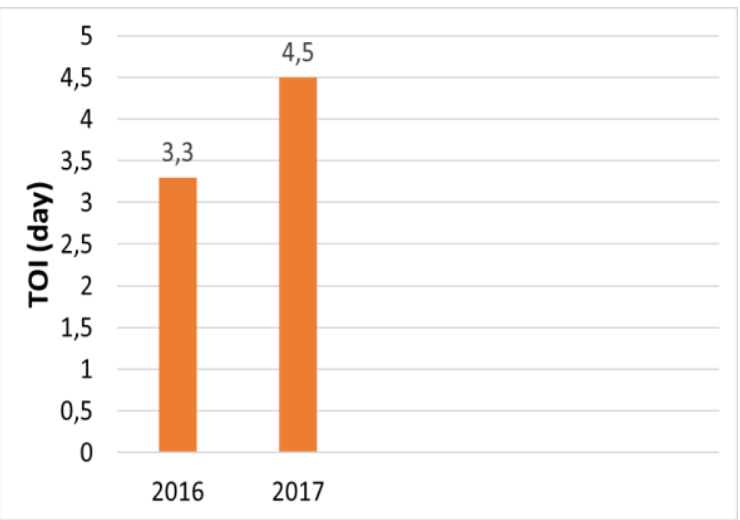

Figure 4. TOI of the Sorong Naval Hospital dr. R. Oetojo, Indonesian Navy

Source: Data of Naval Hospital dr. R. Oetojo, Indonesian Navy, 2018

One study of SERVQUAL, according to Parasuraman in Ratnasari and Aksa there are five dimensions SERVQUAL ${ }^{9}$. They suggested that there are five dimensions that are utilized to assess the quality of services, namely: 1) Direct evidence (tangibles), including physical facilities, equipment, staff, and means of communication; 2) reliability, or the ability to provide service in immediate, accurate, and satisfactory result; 3 ) responsiveness, or the passion of the staff to help customers and provide a fast service; 4) guarantee (assurance), including knowledge, skills, courtesy, and trustworthiness owned by the staff; which free from danger, risk or doubt; and 5) Appreciation (empathy), including comfort of the relationship, good communication, personal attention, and understanding the patient needs. Physical evidence (tangible) was measured with eight questions. From the 80 respondents who had become as outpatients or inpatients in the clinic or in the treatment room of the Sorong Naval Hospital dr. R. Oetojo, Indonesian Navy.

patients' answers regarding the perception of outpatient and inpatient care in the clinic or treatment room in the Sorong Naval Hospital dr. R. Oetojo, Indonesian Navy. Recapitulation of the answers showed an average value of physical evidence (tangible) of 4.03 that was on $3: 40$ and $4: 20$ interval range values with the percentage of $80.69 \%$. Physical evidence (tangible) of outpatients or inpatients in the clinic or treatment room in the Sorong Naval Hospital dr. R. Oetojo, Indonesian Navy showed good results. Of the eight questions, the one with the lowest value is concerning the completeness of medical equipment.

Reliability (reliability) was measured by eight questions asked to the respondents. Of the 80 respondents who had become as outpatients or inpatients in the clinic or treatment room in the Sorong Naval Hospital dr. R. Oetojo, Indonesian Navy, the result obtained from the assessment of reliability are listed in Table 3 :
Table 3. Patient Assessment of Reliability $(n=80)$

\begin{tabular}{|c|c|c|c|}
\hline Question & $\begin{array}{l}\text { Alternative } \\
\text { answer } \\
\text { (1) (2) (3) (4) } \\
\text { (5) }\end{array}$ & $\begin{array}{c}\text { Score } \\
\text { Average }\end{array}$ & Criteria \\
\hline $\begin{array}{l}\text {-Patient } \\
\text { acceptance } \\
\text { procedures } \\
\text { are quick } \\
\text { and simple }\end{array}$ & $\begin{array}{c}(1)(3)(14)(54) \\
(8)\end{array}$ & $\begin{array}{l}(305) \\
(3.81)\end{array}$ & Good \\
\hline $\begin{array}{l}\text {-Doctors } \\
\text { come on time }\end{array}$ & $\begin{array}{c}(1)(3)(6)(64) \\
(6)\end{array}$ & $\begin{array}{l}(311) \\
(3.89)\end{array}$ & Good \\
\hline $\begin{array}{l}\text {-Doctors are } \\
\text { ready to serve } \\
\text { patients }\end{array}$ & $\begin{array}{c}(1)(2)(13)(52) \\
(12)\end{array}$ & $\begin{array}{l}(312) \\
(3.90)\end{array}$ & Good \\
\hline $\begin{array}{l}\text {-Doctors serve } \\
\text { patient } \\
\text { quickly }\end{array}$ & $\begin{array}{c}(-)(1)(9)(58) \\
(12)\end{array}$ & $\begin{array}{l}(321) \\
(4.01)\end{array}$ & Good \\
\hline $\begin{array}{l}\text {-Nurses are } \\
\text { ready to serve } \\
\text { patients } \\
\text { everytime }\end{array}$ & $\begin{array}{c}(-)(2)(6)(62) \\
(10)\end{array}$ & $\begin{array}{l}(320) \\
(4.00)\end{array}$ & Good \\
\hline $\begin{array}{l}\text {-Nurses make } \\
\text { report of } \\
\text { every changes } \\
\text { of the patient } \\
\text { to the doctors } \\
\text { visit }\end{array}$ & $\begin{array}{c}(-)(2)(11)(58) \\
(9)\end{array}$ & $\begin{array}{l}(314) \\
(3.92)\end{array}$ & Good \\
\hline $\begin{array}{l}\text {-Nurses } \\
\text { always give } \\
\text { medicine to } \\
\text { the patients } \\
\text { based on } \\
\text { medication } \\
\text { procedure }\end{array}$ & $\begin{array}{c}(1)(1)(3)(65) \\
(10)\end{array}$ & $\begin{array}{l}(322) \\
(4.02)\end{array}$ & Good \\
\hline $\begin{array}{l}\text {-Nurses are } \\
\text { always } \\
\text { standby to call } \\
\text { doctors }\end{array}$ & $\begin{array}{c}(-)(2)(6)(58) \\
(14)\end{array}$ & $\begin{array}{l}(324) \\
(4.05)\end{array}$ & Good \\
\hline Average & & 2529 & \\
\hline $\begin{array}{l}\text { Ideal answer } \\
\text { Percentagee }\end{array}$ & & $\begin{array}{l}3200(3.95) \\
79.03\end{array}$ & Good \\
\hline
\end{tabular}

Source : processed questionnaire, 2019

Table 3. above gives an overall picture of the patient's answers regarding the perception of outpatient and inpatient care in the clinic or treatment room in Naval Hospital dr. R. Oetojo, Indonesian Navy of Sorong City. Recapitulation of the answers showed an average value of reliability of 3.95 that was on 3:40 and 4:20 interval range values with the percentage of $79.03 \%$. The reliability of outpatient or inpatient in the clinic or treatment room in the Sorong Naval Hospital dr. R. Oetojo, Indonesian Navy showed good results. Of the eight questions, the one with the lowest value is the patient acceptance procedures that are quick and simple. 
Responsiveness was measured through six questions. Of the 80 respondents who had become as outpatients or inpatients in the clinic or treatment room in Naval Hospital dr. R. Oetojo, Indonesian Navy of Sorong City that serve as the respondent, the results obtained from the assessment of responsiveness are listed in Table 5 below.

Table 5 provides an overall description regarding the perception of outpatient and inpatient in the clinic or treatment room in the Sorong Naval Hospital dr. R. Oetojo, Indonesian Navy.

Table 4. Patient Assessment of Responsiveness ( $\mathbf{N}=\mathbf{8 0})$

\begin{tabular}{|c|c|c|c|}
\hline Question & $\begin{array}{l}\text { Alternative } \\
\text { answer } \\
\text { (1) (2) (3) (4) } \\
\text { (5) }\end{array}$ & $\begin{array}{c}\text { Score } \\
\text { Average }\end{array}$ & Criteria \\
\hline $\begin{array}{l}\text {-Doctors } \\
\text { always ask } \\
\text { what are } \\
\text { patients' } \\
\text { complaint }\end{array}$ & $\begin{array}{c}(-)(1)(6)(54) \\
(19)\end{array}$ & $\begin{array}{l}(331) \\
(4.14)\end{array}$ & Good \\
\hline $\begin{array}{l}\text {-Doctors ask } \\
\text { the patients }\end{array}$ & $\begin{array}{c}(-)(2)(2)(59) \\
(17)\end{array}$ & $\begin{array}{l}(331) \\
(4.14)\end{array}$ & Good \\
\hline $\begin{array}{l}\text {-Doctors give } \\
\text { explanation } \\
\text { about the } \\
\text { disease/ } \\
\text { illness }\end{array}$ & $\begin{array}{c}(-)(2)(6)(51) \\
(21)\end{array}$ & $\begin{array}{l}(331) \\
(4.14)\end{array}$ & Good \\
\hline $\begin{array}{l}\text {-Nurses are } \\
\text { friendly and } \\
\text { polite }\end{array}$ & $\begin{array}{c}(-)(2)(3)(57) \\
(18)\end{array}$ & $\begin{array}{l}(331) \\
(4.14)\end{array}$ & Good \\
\hline $\begin{array}{l}\text {-Nurses } \\
\text { attentive to } \\
\text { patient } \\
\text { complaint }\end{array}$ & $\begin{array}{c}(1)(1)(6)(57) \\
(15)\end{array}$ & $\begin{array}{l}(324) \\
(4.05)\end{array}$ & Good \\
\hline $\begin{array}{l}\text {-Nurses } \\
\text { attentive to } \\
\text { patients' } \\
\text { family }\end{array}$ & $\begin{array}{c}(3)(2)(8)(60) \\
(7)\end{array}$ & $\begin{array}{l}(306) \\
(3.82)\end{array}$ & Good \\
\hline Average & & 1954 & \\
\hline $\begin{array}{l}\text { Ideal answer } \\
\text { Percentagee }\end{array}$ & & $\begin{array}{l}2400(4.07) \\
81.42\end{array}$ & 7) Good \\
\hline
\end{tabular}

Recapitulation of answers in Table 4. provided an average value of responsiveness of 4:07 that was on 3:40 to 4:20 interval range values with the percentage of $81.42 \%$. Responsiveness according to outpatient or inpatient clinic or treatment room in the Sorong Naval Hospital dr. R. Oetojo, Indonesian Navy showed good results. Of the six questions, the one with the lowest value is the nurses' attention towards patients' family.

Guarantee (assurance) was measured through six questions. Of the 80 respondents who had become as outpatients or inpatients in the clinic or treatment room in the Sorong Naval Hospital dr. R. Oetojo, Indonesian Navy, the results obtained from the assessment of the guarantee (assurance) were shown in Table 6:

Table 5. Patient Assessment of Guarantee (Assurance) $(\mathbf{N}=\mathbf{8 0})$

\begin{tabular}{|c|c|c|c|}
\hline Question & $\begin{array}{l}\text { Alternative } \\
\text { answer } \\
\text { (1) (2) (3) (4) } \\
\text { (5) }\end{array}$ & $\begin{array}{c}\text { Score } \\
\text { Average }\end{array}$ & Criteria \\
\hline $\begin{array}{l}\text {-Specialists are } \\
\text { available }\end{array}$ & $\begin{array}{c}\text { (3) (3) (2) (22) } \\
\text { (41) }\end{array}$ & $\begin{array}{l}(294) \\
(3.67)\end{array}$ & Good \\
\hline $\begin{array}{l}\text {-Doctors } \\
\text { manner give } \\
\text { comfort }\end{array}$ & $\begin{array}{c}(1)(1)(2)(64) \\
(12)\end{array}$ & $\begin{array}{l}(325) \\
(4.06)\end{array}$ & Good \\
\hline $\begin{array}{l}\text {-Nurses is } \\
\text { educated and } \\
\text { able to serve the } \\
\text { patients }\end{array}$ & $\begin{array}{c}(1)(2)(4)(59) \\
\text { (14) }\end{array}$ & $\begin{array}{l}(323) \\
(4.04)\end{array}$ & Good \\
\hline $\begin{array}{l}\text {-The health } \\
\text { treatment } \\
\text { expenses is } \\
\text { affordable }\end{array}$ & $\begin{array}{c}(-)(1)(4)(64) \\
(11)\end{array}$ & $\begin{array}{l}(325) \\
(4.06)\end{array}$ & Good \\
\hline $\begin{array}{l}\text {-Keep patient's } \\
\text { personal } \\
\text { information } \\
\text { /confidenti-ality }\end{array}$ & $\begin{array}{c}(1)(1)(1)(63) \\
(14)\end{array}$ & $\begin{array}{l}(328) \\
(4.10)\end{array}$ & Good \\
\hline $\begin{array}{l}\text {-Give guarantee } \\
\text { to the patient of } \\
\text { healing }\end{array}$ & $\begin{array}{c}(2)(1)(10)(55) \\
(12)\end{array}$ & $\begin{array}{l}(314) \\
(3.92)\end{array}$ & Good \\
\hline Average & & 1909 & \\
\hline Ideal answer & & 2400 (3.97) & Good \\
\hline Percentagee & & 79.54 & \\
\hline
\end{tabular}

Table 6 above gives an overall picture of the patients' answers regarding the perception of outpatient and inpatient care in the clinic or treatment room in the Sorong Naval Hospital dr. R. Oetojo, Indonesian Navy. Recapitulation of the answers provided the average value of assurance of 3.97 that was on $3: 40$ to $4: 20$ interval range values with percentage of $79.54 \%$. Assurance according to outpatient or inpatient clinic or treatment room in the Sorong Naval Hospital dr. R. Oetojo, Indonesian Navy showed good result. Of the six questions, the lowest value is the availability of medical specialists.

Appreciation (empathy) was measured by five questions. Of the 80 respondents who had become as outpatients or inpatients in the clinic or treatment room in the Sorong Naval Hospital dr. R. Oetojo, Indonesian Navy, the obtained results of the assessment of appreciation (empathy) are listed in Table 7 below. From this table, we could identify an overall picture of the patients' answers 
regarding the perception of outpatient and inpatient in the clinic or treatment room in the Sorong Naval Hospital dr. R. Oetojo, Indonesian Navy. Recapitulation of the answers provided an average value of appreciation (empathy) of 4:00 that was on $3: 40$ to $4: 20$ interval range values with the percentage of $80.05 \%$. Appreciation (empathy) according to outpatient or inpatient in the clinic or treatment room in the Naval Hospital dr. R. Oetojo, Indonesian Navy showed good results. Of the five questions, the least value is the nurses spend certain time to communicate with patients.

Table 6. Patient Assessment of Appreciation (Empathy) $(\mathbf{N}=\mathbf{8 0})$

\begin{tabular}{|c|c|c|c|}
\hline Question & $\begin{array}{l}\text { Alternative } \\
\text { answer } \\
\text { (1) (2) (3) (4) } \\
\text { (5) }\end{array}$ & $\begin{array}{c}\text { Score } \\
\text { Average }\end{array}$ & Criteria \\
\hline $\begin{array}{l}\text {-Doctors try to } \\
\text { calm the } \\
\text { patients of their } \\
\text { worries of the } \\
\text { disease }\end{array}$ & $\begin{array}{c}(-)(1)(4)(61) \\
(14)\end{array}$ & $\begin{array}{l}(328) \\
(4.10)\end{array}$ & Good \\
\hline $\begin{array}{l}\text {-Nurses spend } \\
\text { certain time to } \\
\text { commu-nicate } \\
\text { with the patient }\end{array}$ & $\begin{array}{c}(2)(1)(14)(55) \\
(8)\end{array}$ & $\begin{array}{l}(306) \\
(3.82)\end{array}$ & Good \\
\hline $\begin{array}{l}\text {-Nurses always } \\
\text { reminding } \\
\text { patients and } \\
\text { their family to } \\
\text { keep their } \\
\text { belonging } \\
\text { safely. }\end{array}$ & $\begin{array}{c}(1)(1)(3)(65) \\
(10)\end{array}$ & $\begin{array}{l}(322) \\
(4.02)\end{array}$ & Good \\
\hline $\begin{array}{l}\text {-There is } \\
\text { enough time to } \\
\text { make consulta- } \\
\text { tion with the } \\
\text { patient's family }\end{array}$ & $\begin{array}{c}(1)(1)(6)(62) \\
(10)\end{array}$ & $\begin{array}{l}(319) \\
(3.99)\end{array}$ & Good \\
\hline $\begin{array}{l}\text {-Cheer and give } \\
\text { support to the } \\
\text { patients so they } \\
\text { will be cured } \\
\text { fast, and also } \\
\text { pray the } \\
\text { patients }\end{array}$ & $\begin{array}{c}(-)(1)(6)(59) \\
(14)\end{array}$ & $\begin{array}{l}(326) \\
(4.07)\end{array}$ & Good \\
\hline Average & & 1601 & \\
\hline $\begin{array}{l}\text { Ideal answer } \\
\text { Percentagee }\end{array}$ & & \multicolumn{2}{|c|}{$2000(4.00)$ Good } \\
\hline
\end{tabular}

It can be seen on table 8 that the overall quality of services that consists of dimensions of physical evidence (tangible), reliability, responsiveness, guarantee (assurance), and appreciation (empathy) showed the average index of 4.00 or $80.15 \%$. This value means the quality of health services in the Sorong Naval Hospital dr. R. Oetojo, Indonesian Navy has a good average. Quality of service of responsiveness has an average value of 4.07 or $81.42 \%$ as the highest percentage, while the quality of service of reliability has an average value of 3.95 or $79.03 \%$ as the lowest percentage. The lowest indicators in the Sorong Naval Hospital dr. R. Oetojo, Indonesian Navy included the completeness of medical equipments, patient acceptance procedures that are quick and simple, the nurses attention towards patients' family, the availability of medical specialists, and the nurses spend certain time to communicate with patients.

Table 7. Average value of Health Care Service Quality per Dimensions

\begin{tabular}{lccc}
\hline Sub-Variable & Average & $\begin{array}{c}\text { Percen- } \\
\text { tagee (\%) }\end{array}$ & $\begin{array}{c}\text { Gap } \\
\text { Criteria }\end{array}$ \\
\hline -Tangible & 4.03 & 80.69 & 19.31 \\
-Reliability & 3.95 & 79.03 & 20.97 \\
& & & Good \\
-Respon- & 4.07 & 81.42 & 18.58 \\
siveness & & & Good \\
-Assurance & 3.97 & 79.54 & 20.46 \\
& & & Good \\
-Emphaty & 4.00 & 80.05 & 19.95 \\
& & & Good \\
Average & 4.00 & $\mathbf{8 0 . 1 5}$ & $\mathbf{1 9 . 8 5}$ \\
& & & Good \\
\hline
\end{tabular}

Source: processed questionnaire, 2019

The next quantitative data processing which perform multiple linear regression analysis was used to test hypothesis about the partial effect of independent variables on the dependent variables. Based on estimation of multiple regression with SPSS program obtained the following results as described in Table 8:

From Table 9 above, we obtained $\mathrm{a}=0274 \mathrm{~b} 2 \mathrm{~b} 1=$ $0.053=0.090=0.0685 \mathrm{~b} 4 \mathrm{~b} 3=0162$ and $\mathrm{b} 5=0.0821$ it can be seen that the regression equation is:

$$
\mathrm{Y}=0274+0.053 \mathrm{X} 1+0.090 \mathrm{X} 2+0.068 \mathrm{X} 3+0.162 \mathrm{X} 4
$$

$+0.082 \mathrm{X} 5+\varepsilon$

The above equation means that if $\mathrm{X} 1$ Physical evidence (tangible) perceived better and X2, X3, X4 and $\mathrm{X} 5$ are constant, the value of $\mathrm{Y}$ that is the satisfaction of patients will increase by 0053 . If $\mathrm{X} 2$ reliability perceived better and $\mathrm{X} 1, \mathrm{X} 3, \mathrm{X} 4$ and $\mathrm{X} 5$ are constant, the value of $\mathrm{Y}$ that is the satisfaction of patients will increase by 0.090 . If $\mathrm{X} 3$ responsiveness perceived better and $\mathrm{X} 1, \mathrm{X} 2, \mathrm{X} 4$ and $\mathrm{X} 5$ are constant, the value of $\mathrm{Y}$ that is the satisfaction of patients will increase by 0068 . If $\mathrm{X} 4$ guarantee (assurance) perceived better and $\mathrm{X} 1, \mathrm{X} 2 \mathrm{X} 3$, and $\mathrm{X} 5$ are constant, the value of $Y$ that is the satisfaction of patients will increase 
by 0162 , and if $\mathrm{X} 5$ appreciation (empathy) perceived better and $\mathrm{X} 1, \mathrm{X} 2, \mathrm{X} 3$, and $\mathrm{X} 4$ are constant, the value of $\mathrm{Y}$ that is the satisfaction of patients will increase by 0082 .

Table 8. Result Statistic t-test Coefficients Dependent Variable: Effect Service Quality to Patient Satisfaction

\begin{tabular}{|c|c|c|c|c|c|c|}
\hline \multirow{3}{*}{\multicolumn{2}{|c|}{ Model }} & \multicolumn{5}{|c|}{ Unstandardized Standardized } \\
\hline & & \multirow[b]{2}{*}{ B } & \multicolumn{3}{|c|}{ Coefficients Coefficients } & \multirow[b]{2}{*}{ Sig. } \\
\hline & & & $\begin{array}{l}\text { Std. } \\
\text { Error }\end{array}$ & Beta & $\mathbf{t}$ & \\
\hline \multirow[t]{6}{*}{1} & (Constant) & .274 & .705 & & .389 & .699 \\
\hline & -Tangible & .053 & .031 & .148 & 1.715 & .021 \\
\hline & -Reliability & .090 & .038 & .179 & 2.396 & .019 \\
\hline & $\begin{array}{l}\text {-Respon- } \\
\text { siveness }\end{array}$ & .068 & .018 & .260 & 3.855 & .000 \\
\hline & -Assurance & .162 & .047 & .247 & 3.440 & .001 \\
\hline & -Emphaty & .082 & .026 & .249 & 3.090 & .003 \\
\hline
\end{tabular}

Source: processed questionnaire, 2019

Analysis of determination was used to explain how big the influence of independent variable (X) with variable of health care service quality of physical evidence (tangible), reliability, responsiveness, guarantee (assurance), and appreciation (empathy) dimensions to the dependent variable $(\mathrm{Y})$ of patient satisfaction. The coefficient of determination was calculated by squaring the correlation coefficient that has been found and multiplied it by $100 \%$. The calculation results can be seen in Table 10:

Table 9. Coefficient of Determination

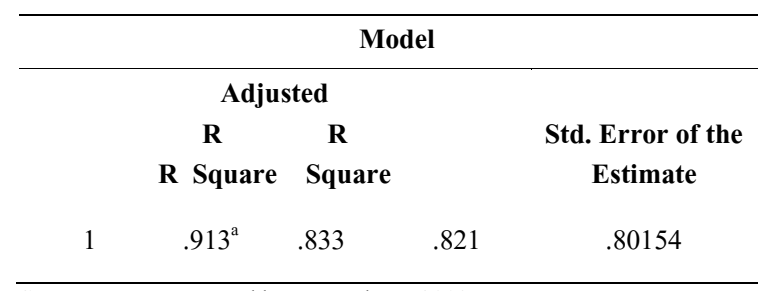

Source: Data processed by researchers, 2019

Table 9 showed the value of the coefficient of determination of $83.3 \%$, based on the following calculation:

$$
\begin{aligned}
\mathrm{KD} & =(0.913)^{2} \times 10 \\
& =83.3 \%
\end{aligned}
$$

This value means that the effect of quality health services variable with physical evidence (tangible), reliability, responsiveness, guarantee (assurance), appreciation (empathy) dimensions to patients satisfaction in the Sorong Naval Hospital dr. R. Oetojo, Indonesian Navy was $83.3 \%$ with the remaining $16.7 \%$ was influenced by other factors not included in this study, such as the cost service variable.
The effect of patient satisfaction to patient trust was $83.3 \%$, indicating that satisfaction is closely related to the quality of service. Quality of service is one of the components that produce customer satisfaction besides the quality of products and prices. Quality of service is a reflection of services that includes interaction quality, physical environment quality, and outcome quality. The quality of service as one of the components provided by the service provider affects customer satisfaction as well as the influence of situational factors and personal factors.

Those results are consistent with Edgett's study that the success or failure of a business will be determined by three main determinants: customer satisfaction, quality of products/ services and products/services performance. ${ }^{10}$ While Muffato's in his research believes that customer satisfaction is the culmination point of efforts to make improvements of a business entity. This is one important factor that can be a measure of success of business entity in its efforts to stay in the industry, which is the ability of it in giving satisfaction to their customer. ${ }^{11}$

Kaplan stated that there are three categories in the service attributes that contribute directly to the development of values, each of which is (1) Attributes of products and services related to function, quality, price and time; (2) Relationships with the customers related to comfort, personal advice, and responsiveness and (3) Image and reputation associated with knowledge. ${ }^{12}$

To be able to continuously present services with a high level of quality, a company is expected to continuously increase the value of the services anyway. That is because basically the perception of value of service is a reflection of how high the quality of these services in the customer's perception (Heskett in Tjiptono, 2012). Further Heskett stated that the high perception of a customer to a service, as described above, is the orientation of most service providers. All elements in the company should strive to convince customers as much as possible, that the customers receive greater benefit compared to the cost or efforts they have spent. ${ }^{13}$

Modernity with advances in technology will result in a very high competition to acquire and retain customers. Quality of services become a necessity that must be done by companies so that they can survive and win the trust of customers. Consumption patterns and customers lifestyle demand companies to provide a quality service. The company's success in providing a quality service can be determined with the approach of service quality developed by Parasuraman, Berry and Zenthaml. Service Quality is how much the difference between customers expectation and the reality of the services they receive. Service Quality can be determined by comparing customers' perception of 
the services and the actual services they actually receive. Quality of service become the main factor companies pay attention to, that include all companies resources. ${ }^{14}$

According to Wyckof, service quality is the level of excellence expected and control over the level of excellence to meet customer expectation. If the services received as expected, the perceived service quality is good and satisfactory. If the services received exceed the expectations of customers, the perceived service quality is ideal. In the contrary, if the services received are lower than expected, the quality of service is considered as bad. ${ }^{15}$

Trust is the belief of a party towards the purpose and behavior of the other party. Thus the consumer trust is defined as consumer expectation that service providers can be trusted or relied on meeting their promises. ${ }^{16}$ Trust is considered as an action, behavior or orientation, a relationship. ${ }^{17}$ While others still believe that trust is a natural feeling or a belief, where a person is willing to act. ${ }^{18}$ Trust has been described as an act of cognitive (eg., a form of opinion or prediction that something will happen or people will behave in a certain way), affective (eg., a feeling) or conative (eg., preference or desire). There are four (4) form of trust, namely the destination-based trust, calculation-based trust, knowledge-based trust and awardsbased trust. Confidence is obviously very useful and important in building a relationship, despite being a trusted party is not easy and requires a big effort. The following factors contribute to the formation of the trust, ie., values, reliance on the other parties, an open and frequent communication, and practicing opportunism. ${ }^{19}$ Commitment and trust are the two most important components of a longterm relationship between companies and partners or customers.

Kau and Loh (2010) stated that there is a positive relationship between customer satisfaction and service quality, as well as customer satisfaction and trust. This study provides a rational basis for problem analysis and determination of research concepts and variables in research, namely quality of service, customer satisfaction, and customers trust to the services. ${ }^{20}$

Internal environmental analysis can be determined in a number of ways including calculating risk, measuring achievement such as assessing service quality and customer satisfaction. The process of conducting internal and external environmental analysis involves leaders, staff and members in determining strengths and weaknesses. Systematic identification of internal and external factors in formulating hospital strategies is known as the most popular model for situation analysis is SWOT analysis. ${ }^{21}$

According to Pearce and Robinson (2010), SWOT is an acronym for Strengths (power) and Weaknesses of a company's internal and Opportunities and Threats from the environment. Analysis of this external and internal environment is based on the assumption that an effective strategy is derived from a good "appropriateness" between internal resources (strengths and weaknesses) and external situation (opportunities and threats). A great appropriateness will maximize the strengths and opportunities of the company, and minimizing weaknesses and threats. ${ }^{22}$

Hashemi (2012) stated that in conducting business analysis of external and internal environment, companies should adopt a SWOT analysis. SWOT Analysis is a summary key of the business environmental issues and development strategies. It is useful as a basis in determining choices of future strategy. This study used the SWOT analysis that examines aspects of the external environment (the opportunities and threats) and internal environment (strengths and weaknesses). ${ }^{23}$

The factors that influence health services in the Sorong Naval Hospital dr. R. Oetojo, Indonesian Navy, will be explained through the identification of internal environment that includes strengths and weaknesses. Strength consists of: the availability of health workers in accordance with the field and available health workers in accordance with the standards and competencies set by the Ministry of Health, increased hospital funding, a good rate of budget absorption, a great work motivation, a good marketing efforts, and the presence of vision and mission. Weaknesses consists of: the function of hospital services which include medical services and pharmacy services that are not adequate, Human Resources (medical) and non-medical that is inadequate as a lack of general practitioners, dentists, main specialists and supporting specialists, the lack of Human Resources (Pharmacy), the lack of human resources (nurses), inadequate infrastructure and facilities such as a patient bed and the hospital building area. Besides, there are still human resources that are not in accordance with the job description and the placement, and lack of medical personnel, paramedics and general workers.

The identification of the external environment was in the form of opportunities and threats. Opportunities consisted of: the development status of the hospital that change into hospital type II, opportunities of increasing the types of services, opportunities for developing product services, changing patterns of financial independence and the development of Strategic Business Unit, a growing number of people. Threats consist of: the existence of private clinics or physicians practice with the status of first level health care that increase continuously in numbers and its facilities, socio-economic conditions around the hospital that are still relatively low, existence of government regulation, and referral network that is not optimal, and 
public awareness of the independent health financing care insurance through dana sehat that is not well developed.

The table 9 and 10 below showed the determination of the ranking and the weight of each SWOT factor of the Sorong Naval Hospital dr. R. Oetojo, Indonesian Navy. To determine the important variables in the internal environment is the same as the external environment by performing analysis using Internal Factor Evaluation Matrix (IFE /IFAS Matrix) and External Factor Evaluation Matrix (EFE/EFAS matrix) with weighting and ranking value through Consencus Decision Making Group (CDMG).

Table 11. Matrix IFAS (Internal Factor Analysis Summary)

\begin{tabular}{|c|c|c|c|}
\hline Internal Factor & Weight & Rank & Score \\
\hline \multicolumn{4}{|l|}{ Strength } \\
\hline $\begin{array}{l}\text { 1. Medical workers that are } \\
\text { suitable with the health } \\
\text { care standard }\end{array}$ & 0.091 & 4 & 0.364 \\
\hline $\begin{array}{l}\text { 2. An increased hospital } \\
\text { revenue }\end{array}$ & 0.084 & 3 & 0.252 \\
\hline $\begin{array}{l}\text { 3. Budget absorption level } \\
\text { is good }\end{array}$ & 0.104 & 4 & 0.416 \\
\hline 4. A good work motivation & 0.103 & 3 & 0.309 \\
\hline $\begin{array}{l}\text { 5. Marketing efforts of } \\
\text { health service }\end{array}$ & 0.113 & 3 & 0.339 \\
\hline 6. Vision and mission & 0.084 & 3 & 0.252 \\
\hline Amount & 0.579 & & 1.932 \\
\hline Weakness & & & \\
\hline $\begin{array}{l}\text { 1. Hospital services that } \\
\text { include medical and } \\
\text { pharmacy services are not } \\
\text { adequate }\end{array}$ & 0.108 & 4 & 0.432 \\
\hline $\begin{array}{l}\text { 2. Human resources } \\
\text { (medical- non medical) are } \\
\text { not adequate }\end{array}$ & 0.109 & 3 & 0.327 \\
\hline $\begin{array}{l}\text { 3. Inadequate facilities and } \\
\text { infrastucture }\end{array}$ & 0.104 & 3 & 0.312 \\
\hline $\begin{array}{l}\text { 4. Human resources that } \\
\text { are not suitable with job } \\
\text { description }\end{array}$ & 0.100 & 2 & 0.200 \\
\hline Amount & 0.421 & & 1.271 \\
\hline Total & 1.00 & & 3.203 \\
\hline
\end{tabular}

\section{Description:}

\section{Strength:}

Scale 4 = is a good / large- scale of strength

Scale $3=$ is a medium-scale of strength

Scale $2=$ a small-scale of strength

Scale $1=$ a very small-scale of strength
Weakness:

Scale $4=$ a very small-scale of weakness / none Scale $3=$ a small-scale of weakness

Scale 2 is a medium- scale of weakness

Scale $1=$ is a large-scale of weakness

opportunity:

Scale 4 = a good/ large -scale of opportunity

Scale 3 = is a medium-scale of opportunities

Scale 2 = a small-scale of opportunities

Scale $1=$ a very small-scale of opportunities / none

Threat:

Scale 4 = a very small-scale of threat / none

Scale 3 = a small-scale of threat

Scale 2 is a medium-scale of threat

Scale $1=$ is a large-scale of threat

Table 12. Matrix EFAS (External Factor Analysis Summary)

\begin{tabular}{|c|c|c|c|}
\hline $\begin{array}{l}\text { External Factor } \\
\text { Opportunities }\end{array}$ & Weight & Rank & Score \\
\hline $\begin{array}{l}\text { 1. Development of hospital } \\
\text { status }\end{array}$ & 0.102 & 4 & 0.408 \\
\hline $\begin{array}{l}\text { 2. Opportunities to } \\
\text { increase completeness of } \\
\text { services }\end{array}$ & 0.095 & 3 & 0.285 \\
\hline $\begin{array}{l}\text { 3. Opportunities of product } \\
\text { service development }\end{array}$ & 0.187 & 4 & 0.748 \\
\hline $\begin{array}{l}\text { 4. The changing of funding } \\
\text { pattern become more }\end{array}$ & & & \\
\hline $\begin{array}{l}\text { independent and USB } \\
\text { development (Unit Strategi } \\
\text { Bisnis) }\end{array}$ & 0.107 & 3 & 0.321 \\
\hline 5. Increased of society & 0.095 & 3 & 0.285 \\
\hline $\begin{array}{l}\text { Amount } \\
\text { Threats }\end{array}$ & 0.586 & & 2.047 \\
\hline $\begin{array}{l}\text { 1. Private clinics and } \\
\text { physicians practice as } \\
\text { competitors }\end{array}$ & 0.101 & 2 & 0.202 \\
\hline $\begin{array}{l}\text { 2. Low social economic } \\
\text { condition in the } \\
\text { environment }\end{array}$ & 0.090 & 3 & 0.27 \\
\hline 3. Government regulation & 0.029 & 2 & 0.058 \\
\hline $\begin{array}{l}\text { 4. Referral network that is } \\
\text { not optimal }\end{array}$ & 0.099 & 3 & 0.297 \\
\hline $\begin{array}{l}\text { 5. Public awareness of the } \\
\text { independent health }\end{array}$ & & & \\
\hline $\begin{array}{l}\text { financing care insurance } \\
\text { through dana sehat that is } \\
\text { not well developed }\end{array}$ & 0.095 & 3 & 0.285 \\
\hline Amount & 0.414 & & 1.112 \\
\hline Total & 1.00 & & 3.159 \\
\hline
\end{tabular}


Scores from each of these SWOT factors will provide an overview of health services degree in the Sorong Naval Hospital dr. R. Oetojo, Indonesian Navy. Health services degree in the Naval Hospital dr. R. Oetojo, Indonesian Navy can be seen from the distance between internal factors (Strengths-Weaknesses) and external factors (Opportunities-Threats). The distance is the internal factor of 0661 (1932-1271), while the distance in the external factors is 0935 (2047-1112). Hence, the position of grand strategy lies greater on a opportunity than on threat, while the strength is greater than the weakness (0661: 0935), which is shown at the position in Figure 5 below:

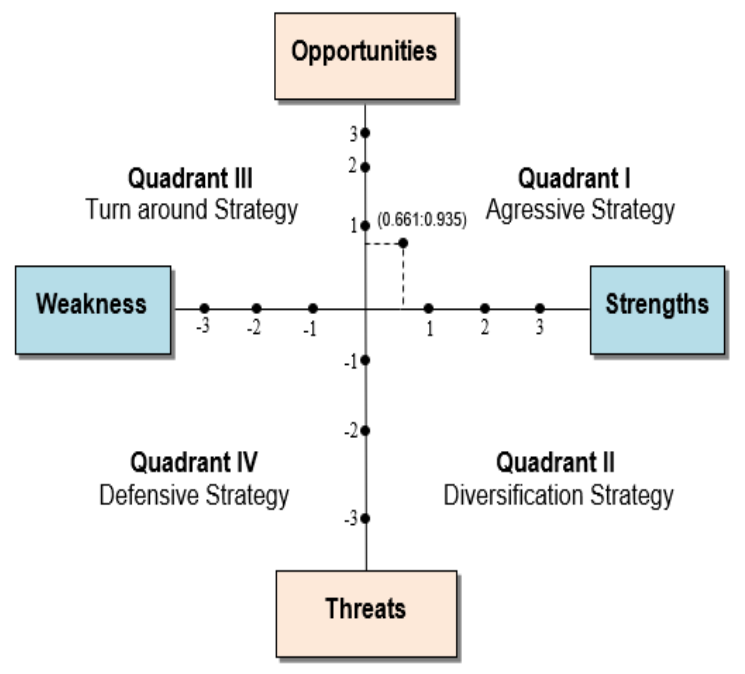

Figure 5. Health Service SWOT Analysis Diagram Naval Hospital dr. R. Oetojo, Indonesian Navy Source: Data processed by the researcher, 2019

Health services in the Sorong Naval Hospital dr. R. Oetojo, Indonesian Navy based on SWOT analysis diagram in figure 5 above is located in Quadrant I, which is an aggressive strategy, where the health services in the Sorong Naval Hospital dr. R. Oetojo, Indonesian Navy is in a strategic position: the most favorable position, where the hospital has the opportunity and the power that can maximize collecting advantages of existing opportunities. It would be beneficial if the hospital adopt strategies that support an aggressive growth policy.

Based on the strategic position of health services of the Sorong Naval Hospital dr. R. Oetojo, Indonesian Navy in the first quadrant, it may have several alternative strategies by using its strenght to take advantage of opportunities.

Alternative strategies that may be carried out in the Sorong Naval Hospital dr. R. Oetojo, Indonesian Navy based on matrix is market development- the status development of the hospital into type II hospital (existing products are sold to the new market) as well as product development- the development of new products such as adding health care facilities for patients (new product are developed for the existing markets).

Phase Matching (Matching Stage) is the process of positioning the organization based on the analysis of strengths and weaknesses that are owned by the Sorong Naval Hospital dr. R. Oetojo, Indonesian Navy and the significance of the opportunities and threats of the organization's external environment. It can be analyzed using SWOT Matrix and Matrix IE (Internal-External Matrix) based on the identification of internal and external factors of the Sorong Naval Hospital dr. R. Oetojo, Indonesian Navy that describes the strengths and weaknesses that are owned by the hospital and the opportunities and threats faced. The combination of companies' internal and external factors was arranged in a systematic and structured way so it produced four kinds of strategies. Those are the form of strategy S-O, S-T, W-O and W-T.

A more detailed explanation of the strategies resulted from the SWOT matrix in Table 11 are as follows:

\section{S-O Strategies (Strength-Opportunity)}

SO strategy is a strategy that uses the internal strength of hospitals to reach opportunities outside the hospital. Strategies that can be used are: professional health staff that work in accordance with their sectors and subspecialists will be optimized in flagship programmes activities product, a good employee's work motivation will maintain and increase loyalty of old and new patients in accordance with the vision and mission of hospitals, the marketing unit will seek to do the marketing related with subspecialists health service, clinic services in the afternoon, and a flagship products. These strategies are expected to raise a lot of visitors and companies to use outpatient unit in order to increase hospital revenue.

\section{S-T Strategy (Strength-Threath)}

S-T strategy is a strategy that uses the hospital internal strength to avoid or reduce the impact of threats come from outside the hospital. The S-T Strategy produced are: professional health staff or medical professionals in accordance with their work field and a good motivation to work well as the power to confront competitors, hospital revenue increases and budget absorption level that can address the low social conditions, and the marketing efforts that can increase referral networks become more optimal.

\section{W-O Strategy (Weakness-Opportunity)}

WO strategy is a strategy that is used to minimize hospital internal weaknesses and exploit the opportunities outside the hospital. The W-O strategy generated are: the narrow waiting room and limited parking areas can be 
overcome with the afternoon clinic services, limited bed facility can be overcome by collaborating with other health facilities by adding the amount of room on the lateral development of buildings, a decrease of patients visit can be improved by taking the cooperation with other health facilities and create a superior product service.

\section{W-T Strategy (Weakness-Threat)}

W-T strategy is a strategy to survive by reducing internal weaknesses and avoiding threats. Strategies that can be used are: the management must work together to overcome limitation in lounge area, parking space, and existence of competitors by accelerating the realization of lateral building development and the afternoon clinic services, the decline of patients visit can be solved by optimizing the marketing units and continue the reactivation of askes gakin and jamkesmas for those who cannot afford the payment, the pharmacy must fulfill the minimal amount of drugs by filing a change of government regulation on the standard drug formulary.

The next stages is preparing a matrix IE (internalexternal) that is useful to put into position the SBU (Strategic Business Unit) organization to a matrix consisting of nine cells by looking at the total value of IFAS and EFAS. Matrix IE puts various divisions of the organization in the schematic diagram, so it can be referred to as the portfolio matrix. IE matrix with a horizontal axis $\mathrm{X}$ is the value of IFAs which is divided into three regions, namely:

$$
\begin{aligned}
& 1.0-1.99=\text { IFAS weak } \\
& 2.0-2.99=\text { IFAS medium } \\
& 3.0-4.0=\text { IFAS strong }
\end{aligned}
$$

IE matrix with a vertical $\mathrm{Y}$ axis is the value of EFAS that is divided into three regions, namely:

$$
\begin{aligned}
& 1.0-1.99=\text { EFAS low } \\
& 2.0-2.99=\text { EFAS medium } \\
& 3.0-4.0=\text { EFAS high }
\end{aligned}
$$

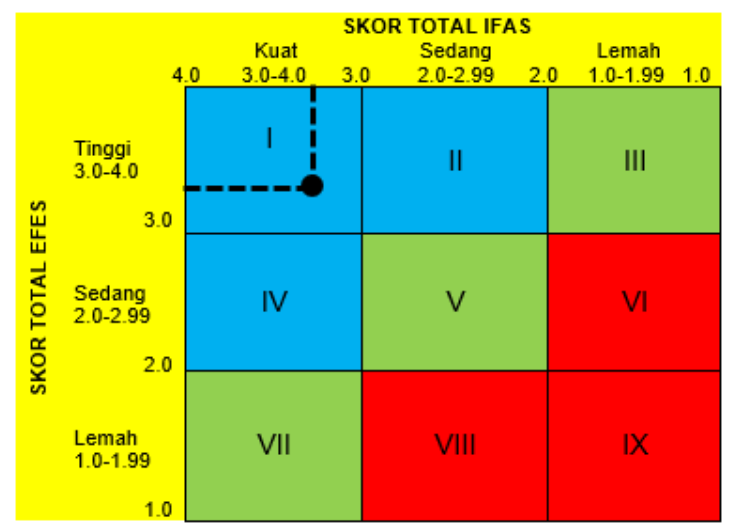

Figure 6. Matrix IE (Internal-External)

Source: Data Processed by Researcher, 2019
From the results of the evaluation matrix of IFAS and EFAS, it was obtained a total IFAS of 3,203, while EFAS is 3,159 . Based on these values that is shown in Figure 6 above it can be seen that the position of the Sorong Naval Hospital dr. R. Oetojo, Indonesian Navy is located on the upper left box or cell I (can be described as Grow and Build). It showed that the strategy can be taken is the intensive strategy consists of: market penetration, market development, and product development; and integrative strategy consists of: backward integration, forward integration and horizontal integration.

Based on the results of IE matrix above, alternative strategies or chosen strategies can be obtained for the Sorong Naval Hospital dr. R. Oetojo, Indonesian Navy for the next five years in accordance with the conditions, situation and the position of the current organization, namely the development of building facilities and health care products through selected strategies that can be done gradually and in stages. The chosen strategy can be customized with alternative strategies from the SWOT matrix analysis by always considering the understanding of each of these strategies. Furthermore, if some of these strategies have the same goals they can be grouped together.

After going through stages of matching (matching stage) alternative strategy/chosen strategies selected from the results of two matrices to produce a suitable strategy for the Sorong Naval Hospital dr. R. Oetojo, Indonesian Navy for the next five years, the result of both strategy match is the development of the infrastructure facility and health care products. Hence, it can be promoted in healthcare delivery in Sorong or as a referral/ supporting hospital in eastern region so it can minimize financing aspect / the cost value.

Here are the key strategies and critical success factors that can be applied in the development strategy of the Sorong Naval Hospital dr. R. Oetojo, Indonesian Navy in providing health service delivery, namely: commitment to raise and cultivate the principles in the provision of services that focused on customer, build up professionalism and work behavior of human resources, development of infrastructure which supports the quality of health services, the development of the type and scope of service, the development of marketing health services, a high quality and superior health services, high commitment, moral faith, discipline in achieving patient satisfaction, development of standards operational services, an effective and efficient resources management, the standard distribution of services to improve the welfare of employees, and the development of operational cooperation (KSO) with the third party. 


\section{CONCLUSION}

The results of the research on Management Strategy of the Sorong Naval Hospital dr. R. Oetojo, Indonesian Navy by using impartial approach strategy as a Core Strategic Management System can be summarized as follows: The vision is to "To be an Honored Hospital of the Soldiers, Civil Servant, the Family of Naval Force and Communities in the Region The Sorong XIV Main Naval Base", and its mission is "To Provide a Prime Health Services and Affordable through All Levels of Society, and Organizing Reliable Health Care Support Services, Improve Professionalism of the Human Resources (HR), and Arrangements of Hospital Organization that is QualityOriented, Improving Infrastructures with Quality and patient Safety Orientation". Its motto is "Dharma Husada Rumeksa or Obligation and Devotion, Treatment, and Care". These Vision, mission and motto are still maintained in the Sorong Naval Hospital dr. R. Oetojo, Indonesian Navy until the next five years.

\section{REFERENCE}

1. Undang-Undang Nomor 23 Tahun 1992, tentang Kesehatan, hal. 1-3.

2. Ibid, hal. 5 .

3. https://niad.mil.id/2017/02/dukungan-\&-pelayanankesehatan-harus-sesuai-kebutuhan- prajurit-tni/ diakses pada tanggal 10 Maret 2019, pukul 20.30 WIB.

4. Korompis, G.E.C. (2016). Organisasi dan Manajemen Kesehatan. Buku Kedokteran EGC. Jakarta, hal.143.

5. Ibid.

6. Heene, A., \& Desmidt, S. (2005). Stategie en Organisatie van Publieke Organisaties. Disadur oleh Afiff, F., \& Abdullah, I. (2010). Dalam Manajemen Strategik Keorganisasian Publik. PT. Rafika Aditama. Bandung, hal.35.

7. Herlambang, S. (2016). Manajemen Pelayanan Kesehatan Rumah Sakit (Cara Mudah Memahami Manajemen Pelayanan di Rumah Sakit dan Organisasi Pelayanan Kesehatan Lainnya). Gosyen Publishing. Yogyakarta, hal.78.

8. Peraturan Presiden RI No.107 Tahun 2013, Pelayanan Kesehatan Tertentu Berkaitan dengan Kegiatan Operasional Kemenhan, TNI, dan Kepolisian Negara RI, hal. 9-10.

9. Ratnasari, Tri, R., dan Aksa, M. (2011). Teori dan Kasus Manajemen Pemasaran Jasa. Bogor. Ghalia Indonesia, hal 107-109.

10. Edgett, Jr., James \& Peter., Paul, J. (2004). Marketing Management; Knowledge and Skill. Mac. Graw-Hill Higher Education, hal. 168.
11. Muffato. (2001). Secrets of Customer Relationship Management: it's All About How You Make Them Feel. McGraw-Hill: New York. hal. 92.

12. Kaplan. et Clow K.E. (2012), Services marketing, John Wiley, Sons, New York. hal. 82.

13. Tjiptono, F. (2012). Pemasaran Jasa. Bayumedia Publishing. Anggota IKAPI Jatim. hal. 49.

14. Zeithaml, Bitner and Gremler. (2009). Services Marketing: Integrating Customer Focus Across the firm. Fifth edition. New York. Mc. Graw Hill international Edition. hal. 59.

15. Tjiptono, F., \& Gregorius, Dadi. (2010). Pemasaran Strategis. Yogyakarta: Andi Offset. hal. 93.

16. Singh, J. \& Sirdeshmukh, D. (2010). Agency and trust mechanisms in consumer satisfaction and loyalty judgements, Journal of the Academy of Marketing Science, vol. 28, no. 1: hal. 150-167.

17. Alpern, D., \& Grayson, K. (2007). 'Cognitive and affective trust in service relationship', Journal of Bussiness Research, vol. 58, hal. 500-7.

18. Dasgupta, R.C., Davis, J.H., \& Schoorman, F.D. (2004). An Integratif Model of Organizational Trust', Academy of Management Review, vol. 30, no. 3, hal. 709-34.

19. Peppers and Rogers, M. (2014). Reviewing customer value literature: Comparing and contrasting customer value perspectives. Intangible Capital, hal. 708-729.

20. Kau Ah-Keng \& Loh, Elizabeth Wan-Yiun. (2010). The Effects of Service Recovery on Consumer Satisfaction: a Comparison Between Complainants and Non Complainant. Vol. 20: hal.101-111.

21. Ayunigtyas, D. (2006). Manajemen Strategis Rumah Sakit. Program Pasca Sarjana Kajian Administrasi Rumah Sakit, Jakarta. hal.65

22. Pearce \& Robinson. (2010). Strategic Marketing, Sixth Edition, Irwin McGraw-Hill, Boston. hal. 200.

23. Hashemi, K. (2012). Key Strategic Step in Setting a Business, a Review of Some Basic Entrepreneurial Facts. Journal of American Science 8 (2), hal. 551553. 